\title{
TICK EXPOSURE AND PREVALENCE OF BORRELIA BURGDORFERI ANTIBODIES AMONG HUNTERS AND OTHER INDIVIDUALS EXPOSED TO VECTOR TICKS IN EASTERN POLAND
}

\author{
Anna Pańczukl, Matgorzata Tokarska-Rodak ${ }^{1}$, Dorota Plewik ${ }^{1,2}$, Justyna Paszkiewicz ${ }^{1}$ \\ ${ }^{1}$ Faculty of Health and Social Sciences, Pope John Paul II State School of Higher Education \\ in Biała Podlaska, Poland \\ ${ }^{2}$ Innovation Research Centre, Pope John Paul II State School of Higher Education \\ in Biała Podlaska, Poland
}

\begin{abstract}
Background. Lyme borreliosis is the most frequent tick-borne disease in Europe and North America, and the number of registered cases is on the increase. Frequent presence in the habitats of ticks enhances the risk of tick bites and possible infection with Borrelia burgdorferi spirochetes.

Objective. The aim of the study was to assess the risk of $B$. burgdorferi infection posed to hunters and other individuals exposed to activity-related contact with ticks.

Material and methods. The study was carried out in the northern part of the Lublin Province (eastern Poland) and involved 150 individuals exposed to tick bites (110 hunters and 40 individuals exposed to activity-related contact with ticks). The analysis of sera for the presence of B. burgdorferi IgM and IgG antibodies was carried out. All 150 individuals were tested with the ELISA assay, and positive and borderline results of the assay were verified with the Western blot test. All study participants completed a questionnaire, which provided information about exposure to ticks, application of prophylactic measures, and awareness of Lyme borreliosis.

Results. The ELISA assay revealed a positive or borderline result in at least one of the classes of B. burgdorferi antibodies in $63.3 \%(95 / 150)$ of the individuals (IgM 14.0\%, IgG 63.3\%). Verification carried out with the Western blot test showed a positive or borderline result in at least one of the antibody classes in 38.0\% (57/150) of the examined persons (IgM 2.7\%, $\operatorname{IgG} 36.7 \%)$. Abdomen (56.0\%) and legs (53.7\%) were the most frequently bitten body regions. Tick bites on the abdomen were significantly more frequently declared by hunters. Inspection of the body after returning from natural areas was more popular prophylactic method than use of repellents. Inspection of the body was significantly more often used in the group of the hunters.

Conclusions. The risk of $B$. burgdorferi infection among hunters and other individuals undertaking activities associated with exposure to tick bites in the study area is high.
\end{abstract}

Keywords: Lyme borreliosis, Borrelia burgdorferi, ticks, prophylaxis, hunters

\section{STRESZCZENIE}

Wprowadzenie. Borelioza z Lyme jest najczęstszą chorobą przenoszoną przez kleszcze w Europie i Ameryce Północnej, a liczba rejestrowanych przypadków zachorowań wzrasta. Częsta obecność w siedliskach kleszczy zwiększa ryzyko ukłucia przez kleszcze i możliwe zakażenie krętkami Borrelia burgdorferi.

Cel badań. Celem badań była ocena ryzyka zakażenia B. burgdorferi wśród myśliwych oraz innych osób podejmujących aktywności narażające na kontakt z kleszczami.

Materiał i metoda. Badania przeprowadzono na terenie północnej części województwa lubelskiego (wschodnia Polska) wśród 150 osób narażonych na pokłucia przez kleszcze (110 myśliwych i 40 osób narażonych na kontakt z kleszczami w związku z podejmowaniem innych aktywności). Zbadano surowice w kierunku obecności przeciwciał IgM i IgG anty-Borrelia burgdorferi. U wszystkich 150 osób wykonano test ELISA, a pozytywne i wątpliwe wyniki tego testu zweryfikowano stosując test Western blot. W badaniach zastosowano również autorski kwestionariusz ankiety do oceny ekspozycji na kleszcze, podejmowania działań profilaktycznych oraz samooceny poziomu wiedzy na temat boreliozy z Lyme.

Wyniki. Stosując test ELISA, pozytywny lub graniczny wynik w co najmniej jednej z klas przeciwciał anty-Borrelia stwierdzono u 63,3\% (95/150) badanych (IgM 14,0\%, IgG 63,3\%). Po weryfikacji testem Western blot, pozytywny lub graniczny wynik w co najmniej jednej z klas przeciwciał uzyskano u 38,0\% (57/150) badanych (IgM 2,7\%, IgG 36,7\%). Najczęściej

Corresponding author: Anna Pańczuk, Faculty of Health and Social Sciences, Pope John Paul II State School of Higher Education in Biała Podlaska, 95/97 Sidorska, 21-500 Biała Podlaska, Poland, tel. +48 8334469 14, e-mail: a.panczuk@dydaktyka.pswbp.pl

(C) Copyright by the National Institute of Public Health - National Institute of Hygiene 
deklarowanym miejscem pokłucia przez kleszcze był brzuch $(56,0 \%)$ oraz kończyny dolne $(53,7 \%)$. Pokłucie w okolicy brzucha istotnie częściej deklarowali myśliwi. Oglądanie ciała po powrocie z terenów zielonych okazało się popularniejszą metodą profilaktyki niż stosowanie repelentów. Oglądanie ciała istotnie częściej stosowane było wśród myśliwych.

Wnioski. Ryzyko zakażenia $B$. burgdorferi wśród myśliwych i innych osób podejmujących czynności związane z narażeniem na ukąszenia kleszczy na badanym obszarze jest wysokie.

Słowa kluczowe: borelioza z Lyme, Borrelia burgdorferi, kleszcze, profilaktyka, myśliwi

\section{INTRODUCTION}

Lyme borreliosis is one of the newly emerging or re-emerging diseases. It is the most frequent tickborne disease in Europe and North America, and the number of registered cases is on the increase [24]. In Poland, cases of Lyme disease have had to be reported and registered since 1996 and they are characterised by a growing incidence according to the National Institute of Public Health. The highest number of cases (21 514) was reported in 2017, and the incidence rate of the disease reached 56.0/100 000 individuals [9].

Bacteria Borrelia burgdorferi sensu lato transmitted by ticks from the genus Ixodes are the aetiological agents of Lyme borreliosis. In Central Europe, including Poland, Ixodes ricinus is the most common tick species and plays the most important role in transmission of spirochetes, which cause Lyme borreliosis. Frequent presence in the habitats of these arthropods enhances the risk of tick bites and possible infection with $B$. burgdorferi spirochetes. The particularly high risk is posed to foresters, farmers, hunters, and those who collect groundcover fruits or visit tick habitats for recreational purposes (e.g. survival) [21].

The available literature provides many reports analysing the exposure to infection with $B$. burgdorferi spirochetes. Foresters are examined most frequently, while farmers, who are occupationally exposed to tick-borne diseases, are analysed less often $[7,16,19$, 25]. Few studies have been conducted on individuals exposed to other activity-related contact with ticks. Although hunting is popular in Europe, there hed been relatively few studies heretofore that addressed serological exposure of hunters to B. burgdorferi s.l. $[5,10]$.

The aim of the study was to assess the risk of B. burgdorferi infection posed to hunters and other individuals exposed to activity-related contact with ticks by analysis of tick exposure, presence of anti- $B$. burgdorferi antibodies, preventive measures taken to reduce the risk of contracting Lyme disease, as well as awareness and knowledge of the disease.

\section{MATERIALS AND METHODS}

The investigations involved 150 respondents exposed to tick bites; $73.3 \%$ (110/150) were represented by hunters and the other $26.7 \%$ (40/150) were tick bite-exposed individuals undertaking different activities (agriculture, collecting groundcover fruits, recreational activity in forested areas).

The study was carried out in the northern part of the Lublin Province, in eastern Poland. The residents of the city and the countryside accounted for $52.0 \%$ and $48.0 \%$, respectively. They were aged $17-80$ years (mean: 53; $\mathrm{SD}=11$ ). Males, representing $82.7 \%$ of the total number, were a majority of the examined group.

The analysis of sera for the presence of $B$. burgdorferi $\operatorname{IgM}$ and $\operatorname{IgG}$ antibodies was carried out with a routine two-stage serological diagnosis of Lyme disease. The first stage consisted in determination of anti- $B$. burgdorferi sensu lato IgG and IgM antibodies with the ELISA method (Anti-Borrelia ELISA IgM and Anti-Borrelia plus VlsE ELISA IgG, Euroimmun). The wells were coated with mixed antigens of $B$. burgdorferi sensu stricto, B. afzelii, B. garinii and recombinant protein VlsE. In accordance with the producer's recommendations, a result above $22 \mathrm{RU} /$ $\mathrm{ml}$ was considered positive, whereas a result within $16-22 \mathrm{RU} / \mathrm{ml}$ was regarded as borderline. The positive and borderline results obtained were confirmed using the Western blot method (Wb) (Anti-Borrelia EUROLINE-WB IgM/IgG; Euroimmun). Test stripes comprised immobilized antigens of $B$. afzelii ( $\mathrm{p} 83$, p41, p39/BmpA, p31/OspA, p30, p25/OspC, p21, p19, p17/DbpA) as well as a chip with recombinant antigen VlsE. The results were read using the EuroLinescan software (Euroimmun).

After obtaining informed consent, the subjects were asked to fill in a questionnaire including data about the age, sex, number of tick bites, body regions of tick bites, methods for tick removal, frequency of application of repellents, frequency of inspection of the body after returning from tick habitats and self-assessment of the level of knowledge of Lyme borreliosis.

The results were statistically analysed with Pearson's $\mathrm{Chi}^{2}$ test. The analyses were performed using STATISTICA v. 7.1 (StatSoft, Poland). The 0.05 level of significance was adopted for statistical inference.

Consent for the study was obtained from the Bioethics Committee at the Medical University in Lublin (No. KE-0254/12/2013). 


\section{RESULTS}

The ELISA assay revealed a positive or borderline result in at least one of the antibody classes in the case of $63.3 \%(95 / 150)$ of the examined individuals. In the IgM class, a positive result was found for $10.0 \%$ $(15 / 150)$ of the respondents and a borderline result was noted in $4.0 \%(6 / 150)$. In turn, in the IgG antibody class, positive and borderline results were was obtained among $53.3 \%(80 / 150)$ and $10.0 \%(15 / 150)$ of the respondents, respectively (Figure 1).

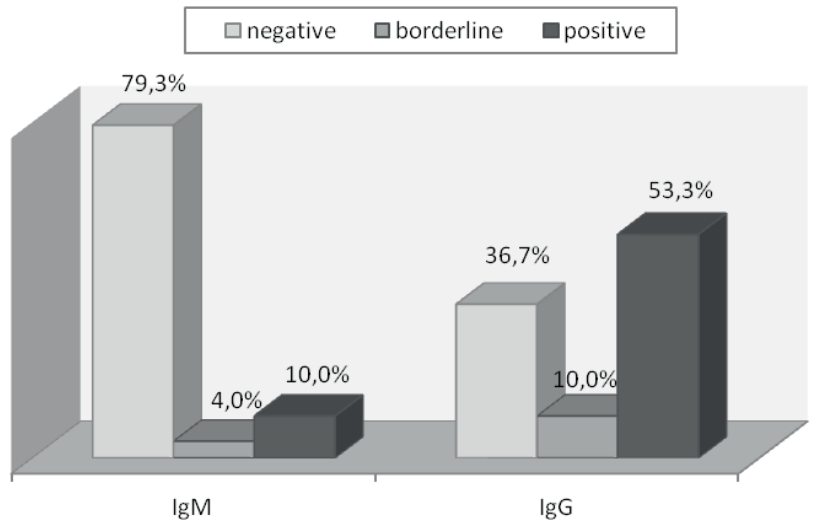

Figure 1. Results of ELISA test with division into $\operatorname{IgM}$ and IgG class antibodies

Positive and borderline results of the ELISA assay were verified with the Western blot test. In the IgM class, there were $0.7 \%(1 / 150)$ of positive results and $2.0 \%(3 / 150)$ of borderline results, and in the IgG class the positive and borderline results accounted for $26.0 \%(39 / 150)$ and $10.7 \%(16 / 150)$, respectively (Figure 2). Ultimately, a positive or borderline result in at least one of the antibody classes was noted in $38.0 \%$ (57/150) of the individuals. A detailed summary of the results is shown in Table 1.

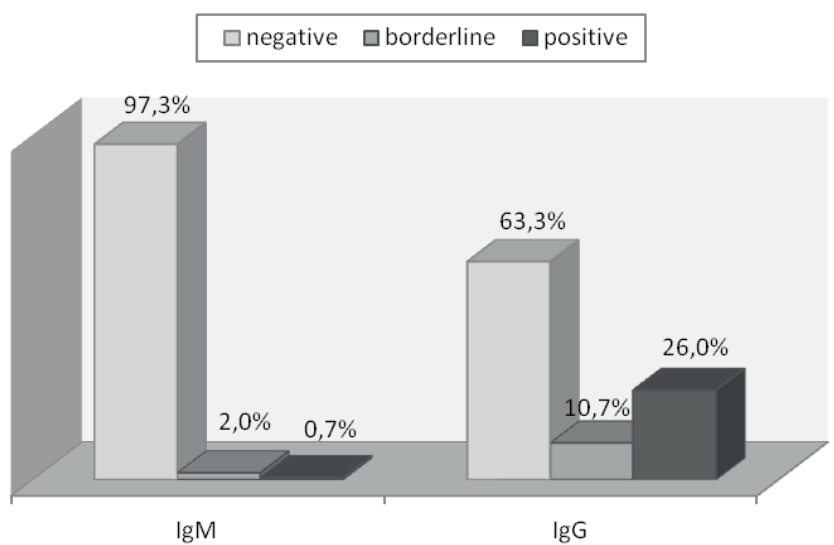

Figure 2. Results of Western blot test with division into $\operatorname{IgM}$ and IgG class antibodies

$89.3 \%(134 / 150)$ of the examined individuals reported having been bitten by a tick. A majority of the respondents $(58.0 \%)$ declared more than two bites, $8.7 \%$ two bites and $22.7 \%$ single bite. Tick bites were declared by $90.0 \%$ in the group of the hunters and by $87.5 \%$ of the respondents undertaking other activities related to tick exposure (agriculture, collecting groundcover fruits, outdoor recreation).

Table 1. Results of ELISA and Western blot tests

\begin{tabular}{|c|c|c|c|c|c|c|c|}
\hline \multirow{2}{*}{\multicolumn{2}{|c|}{$\begin{array}{l}\text { Study group } \\
\qquad N=150\end{array}$}} & \multicolumn{6}{|c|}{ Antibodies against $B$. burgdorferi } \\
\hline & & \multicolumn{2}{|c|}{ ELISA } & \multicolumn{2}{|c|}{$\mathrm{N}=150$} & \multicolumn{2}{|c|}{ Western blot } \\
\hline $\mathrm{n}$ & $\%$ & $\operatorname{IgM}$ & $\operatorname{IgG}$ & $\mathrm{n}$ & $\%$ & $\operatorname{IgM}$ & $\operatorname{IgG}$ \\
\hline \multirow{6}{*}{15} & \multirow{6}{*}{10.0} & \multirow{6}{*}{ positive } & \multirow{6}{*}{ positive } & 1 & 0.7 & positive & negative \\
\hline & & & & 1 & 0.7 & borderline & positive \\
\hline & & & & 3 & 2.0 & negative & positive \\
\hline & & & & 1 & 0.7 & borderline & negative \\
\hline & & & & 1 & 0.7 & negative & borderline \\
\hline & & & & 8 & 5.3 & negative & negative \\
\hline \multirow{3}{*}{6} & \multirow{3}{*}{4.0} & \multirow{3}{*}{ borderline } & \multirow{3}{*}{ positive } & 1 & 0.7 & borderline & positive \\
\hline & & & & 3 & 2.0 & negative & positive \\
\hline & & & & 2 & 1.3 & negative & negative \\
\hline \multirow{3}{*}{59} & \multirow{3}{*}{39.3} & \multirow{3}{*}{ negative } & \multirow{3}{*}{ positive } & 30 & 20.0 & $*$ & positive \\
\hline & & & & 13 & 8.7 & $*$ & borderline \\
\hline & & & & 16 & 10.7 & $*$ & negative \\
\hline \multirow{3}{*}{15} & \multirow{3}{*}{10.0} & \multirow{3}{*}{ negative } & \multirow{3}{*}{ borderline } & 1 & 0.7 & $*$ & positive \\
\hline & & & & 2 & 1.3 & $*$ & borderline \\
\hline & & & & 12 & 8.0 & $*$ & negative \\
\hline 55 & 36.7 & negative & negative & 55 & 36.7 & $*$ & $*$ \\
\hline
\end{tabular}

* - test not performed (the result of ELISA test was negative) 
Abdomen (56.0\%) and legs (53.7\%) were the most frequently bitten body regions reported by the respondents bitten by ticks $(\mathrm{N}=134)$; in turn, the lowest frequency of tick bites was found for the head $(4.5 \%)$ and neck $(9.7 \%)$. Detailed data are presented in Figure 3.

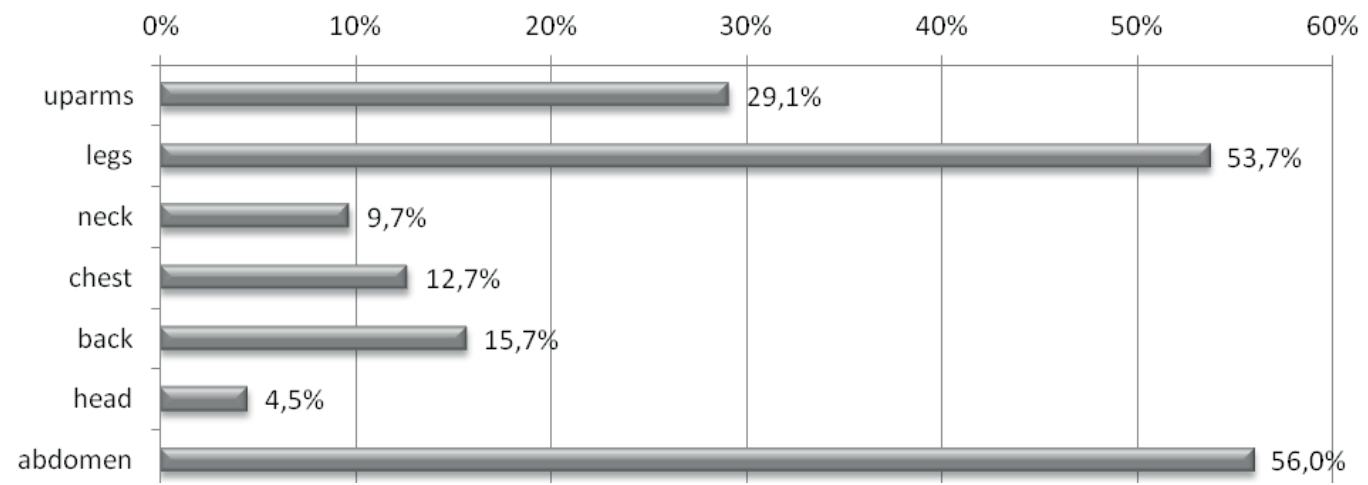

Figure 3. Body regions of tick bites $(\mathrm{N}=134)$

The hunters reported significantly greater numbers of bites on the abdomen than the respondents exposed to contact with ticks through other activities, $62.6 \%$ and $37.1 \%$, respectively $\left(C h i^{2}=6.8 ; \mathrm{p}=0.09\right)$. Additionally, they reported higher frequency of bites on the arms $(32.3 \%)$, chest $(13.1 \%)$, and head $(5.1 \%)$, but the differences were not statistically significant.

Different methods for removal of the tick were used by the respondents bitten by ticks (Figure 4), and pulling the tick out with the fingers was the most frequent method $(36.6 \%)$. Comparative analysis of the groups of the hunters and the other respondents exposed to ticks through their activities showed no statistically significant differences in the frequency of the application of the tick removal methods. Disinfection of the parasite attachment site after the removal was declared by $24.6 \%$ of the individuals.

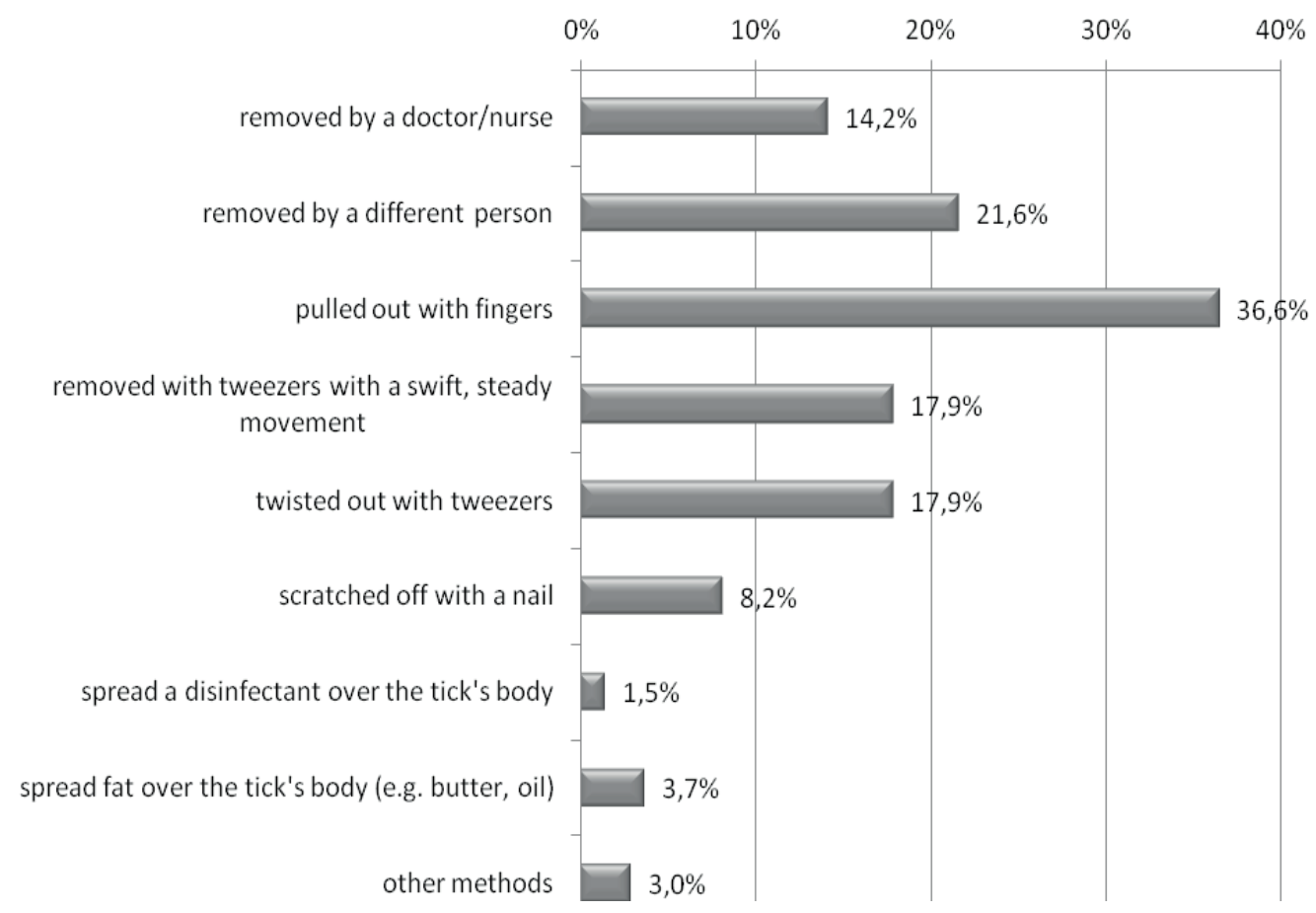

Figure 4. Methods for tick removal applied by the respondents $(\mathrm{N}=134)$

Two Lyme borreliosis prophylactic methods were analysed in the study: the use of tick-repelling agents (repellents) and inspection of the body after returning from tick habitats in order to remove ticks.

As for the use of repellents, the largest group $(42.8 \%)$ of respondents declared that they frequently used this form of prophylaxis (Figure 5). There were no statistically significant differences in the frequency of the use of repellents between the hunters and the other respondents exposed to contact with ticks. 


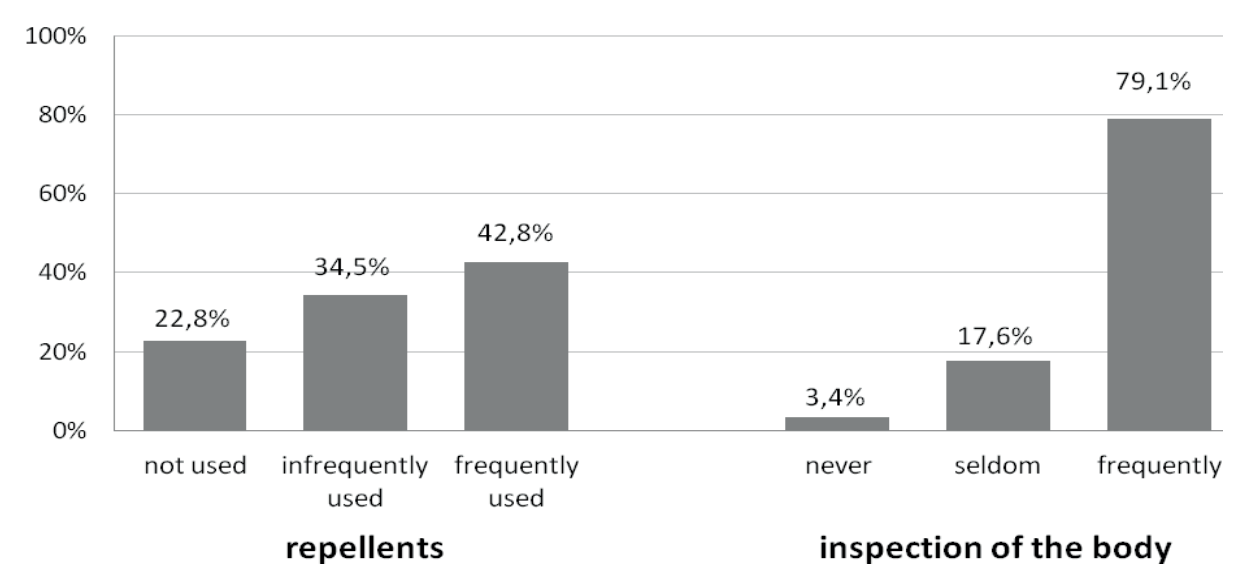

Figure 5. Frequency of application of tick repellents and frequency of inspection of the body after returning from tick habitat

Inspection of the body after returning from natural areas was the most popular prophylactic method. Frequent application of this method was declared by as many as $79.1 \%$ of the respondents (figure 5 ). The method was significantly more often used in the group of the hunters $(86.1 \%)$ than in the group of the individuals exposed to activity-related contact with ticks $(60.0 \%)\left(C h i^{2}=14.4 ; \mathrm{p}<0.01\right)$.

Comparison of the declared frequencies of the use of the two analysed methods reveals that the higher rate of application of repellents by the respondents was accompanied by more frequent inspection of the body $\left(C h i^{2}=17.3 ; \mathrm{p}<0.01\right)$.

The self-assessment of the knowledge of Lyme borreliosis demonstrated that a majority of the respondents evaluated their awareness of the disease at a medium $(52.3 \%)$ or minimal $(33.6 \%)$ level. In this aspect, there were no statistically significant differences between the group of the hunters and the other respondents exposed to tick bites. Individuals that declared inspection of the body after returning from tick habitats assessed their knowledge as medium- or high-level significantly more frequently $\left(C h i^{2}=11.8\right.$; $\mathrm{p}<0.01)$. There were no significant correlations between the self-assessment of the level of knowledge of Lyme disease and the frequency of application of repellents. The need to broaden their knowledge of Lyme disease and other tick-borne diseases was declared by $75.7 \%$ of the respondents.

\section{DISCUSSION}

Frequent presence in the habitats of ticks enhances the risk of tick bites and possible infection with $B$. burgdorferi spirochetes. In the analysed groups of hunters and individuals occupied with activities involving exposure to ticks, there was a high proportion of respondents declaring tick bites (89.3\%). Simultaneously, a majority of the respondents declared having experienced more than two bites $(58.0 \%)$. In a study conducted in the Lublin macroregion, tick bites were reported by $66 \%$ of individuals from an occupationally tick bite-exposed group of foresters and farmers and merely $26 \%$ of occupationally nonexposed individuals [2]. In turn, $58.9 \%$ of secondary school pupils from the analysed region reported tick bites [14].

In our study, the body regions reported most frequently by the individuals who had experienced tick bites included abdomen (56.0\%) and legs $(53.7 \%)$. Tick bites on the abdomen were significantly more frequently declared by the hunters $(62.6 \%)$. Only $37.1 \%$ of the respondents exposed to contact with ticks through other activities reported this site of tick bites. Tick bites on the abdomen are specific to hunters, as the extremities, in particular the legs, are usually the most commonly reported body region bitten by ticks $[1,12,15,20,22,23]$. In the studies among adolescents, performed in the analysed region (northern part of Lublin Province), tick bites on the abdomen and on the legs were declared by $34.4 \%$ and $59.4 \%$ of respondents, respectively [15]. Patients reporting to health facilities in the Lublin Province due to tick bites were most often bitten by ticks on the arms (28.8\%) and legs (27.1\%) [4].

In our study, the ELISA assay revealed positive or borderline results in at least one of the classes of B. burgdorferi antibodies in $63.3 \%$ of the analysed respondents (IgM 14.0\%, IgG 63.3\%). Verification by the Western blot test confirmed a positive or borderline result in at least one of the antibody classes in $38.0 \%$ of the respondents ( $\operatorname{IgM} 2.7 \%$, IgG 36.7\%).

Most publications assessing the presence of $B$. burgdorferi antibodies presented examinations of Lyme disease patients or individuals occupationally exposed to contact with ticks. There are especially many reports of foresters. The investigations, however, were carried out with different diagnostic methods (ELISA, IFA, WB) and in different regions of the individual countries; they are therefore hard to compare. The percentage of foresters having specific antibodies increased in France from 14.1\% to 20.2\%, 
in Italy from $5.4 \%$ to $23.2 \%$, in Germany in the range of $0-43 \%$, in Holland to $19.3 \%$, in Slovenia to $23.8 \%$, in Romania to $9.4 \%$, in Turkey to $10.9 \%$, and in Hungary to $37 \%$. In Poland, the examination results are highly diverse. They range from $19.2 \%$ to $61.5 \%$ in analyses performed with the ELISA test, depending on the region [16]. In examinations of foresters from the same area as in this study, the ELISA assay showed a positive or borderline result in at least one class of antibodies in $75 \%$ individuals, whereas verification with the Western blot test confirmed the results in 55\% (IgM 15\%, IgG 46\%) [19].

In examinations of farmers from the Lublin region (ELISA test), the presence of antibodies from at least one class (IgM or $\operatorname{IgG}$ ) was detected among $27.3 \%$ of the individuals [6]. Further reports from the same region demonstrated the presence of specific antibodies detected using the Western blot method in $33.0 \%$ of farmers [7]. Examinations of farmers from the same area as in this study revealed a positive or borderline result in at least one of the antibody classes in $42 \%$ of individuals examined using the ELISA test and in 28\% of farmers after verification with the Western blot test (IgM 14\%, IgG 18\%) [19].

In the literature, there are few studies relating to hunters. In examinations in Hokkaido (Japan's northernmost island), the presence of antibodies against $B$. burgdorferi was detected among $16.0 \%$ of hunters [13]. In Austria, B. burgdorferi antibodies were detected among $7 \%$ of hunters in the IgM class and $42 \%$ in the IgG class [10]. Further reports from Austria demonstrated the presence of IgG antibodies against B. burgdorferi in 54\% of hunters. Seropositivity was clearly related to age and duration of hunting activity; it was 33\% among persons younger than 29 years and $83 \%$ in those older than 70 years. The nearly linear increase of seroprevalence with age and duration of hunting activity reflects repeated tick exposure [5]. In rural parts of western Turkey, only 1 of $29(3.4 \%)$ serum samples from hunters were positive for IgG B. burgdorferi antibodies [11].

Since no vaccine is currently available, protection against tick bites is the best Lyme borreliosis prophylactic method [19]. In our study, we analysed two methods for Lyme disease prophylaxis: inspection of the body after leaving tick habitats and the use of tick repellents. Inspection of the body was the more popular prophylactic method. A frequent use of this method was declared by as many as $79.1 \%$ of the respondents, and $42.8 \%$ of them reported a frequent use of repellents. Inspection of the body after returning from tick habitats was particularly popular with the hunters. This method was also more frequently applied by individuals who assessed their knowledge of Lyme disease to be at a high level.

In a study conducted in the Lublin macroregion, inspection of the body after leaving tick habitats was declared by $43 \%$ and application of repellents by $38 \%$ of the examined individuals [2]. In other studies in south-eastern Poland, $13 \%$ of patients presenting to a doctor to have a tick removed reported the use of repellents and only $4 \%$ declared inspection of clothes after leaving forests and other tick habitats [3]. The principle of inspection of the body after returning from tick habitats was declared by as many as $92 \%$ of forestry workers and the use of repellents was reported by $76 \%$ [8]. Forest Service employees are well informed about tick-borne diseases, which undoubtedly is related to educational and knowledge dissemination actions provided in this occupational group [26].

An important element of Lyme borreliosis prophylaxis is prompt removal of a skin-attached tick in a proper way. The sooner the tick is removed the greater the chances are that infection does not develop. It is recommended that the tick should be grasped with tweezers as close to the skin as possible and pulled out with a swift, steady, and strong movement. After removal of the tick, the skin should be disinfected [17, 21]. In our study, the most frequent method applied involved pulling the tick out with fingers $(36.6 \%)$. Tick removal with a swift movement using tweezers was declared by $17.9 \%$ of the respondents. Similarly, in other studies conducted in the Lublin macroregion, the most common method for removal of ticks was pulling them out with fingers (44\%). Only $17 \%$ of the respondents declared removing ticks with tweezers [2].

\section{CONCLUSIONS}

The risk of Borrelia burgdorferi infection among individuals undertaking activities associated with exposure to tick bites in eastern Poland is high and spirochete infections confirmed by the positive results of the Western blot test are highly probable. The examined individuals reported most frequent tick bites in the region of the abdomen and legs. Bites on the abdomen were noted with particular frequency in the group of the hunters. The respondents usually evaluated their knowledge of Lyme borreliosis at a medium level. A majority of them declared a need for extension of their knowledge of Lyme borreliosis and other tick-borne diseases.

\section{Acknowledgements}

The investigations were conducted under a research project funded by the Research Grant Fund in Pope John Paul II State School of Higher Education in Biała Podlaska.

We would like to thank A. Szepeluk from Innovation Research Centre, Pope John Paul II State School of Higher Education in Biala Podlaska, for assistance with statistical analysis. 


\section{Conflict of interest}

The authors declare no conflict of interest.

\section{REFERENCES}

1. Aydin M.F., Kocaman H.: Evaluation of tick bites according to anatomical regions on humans in the light of the studies in Turkey. Balikesir Health Sciences Journal. 2015;4(2):122-124.

2. Bartosik K., Kubrak T., Olszewski T., Jung M., Buczek $A$.: Prevention of tick bites and protection against tickborne diseases in south-eastern Poland. Ann Agric Environ Med. 2008;15(2):181-185.

3. Bartosik K, Kubrak T, Sitarz M, Święcicka M., Buczek A.: Stopień zagrożenia mieszkańców południowo-wschodniej Polski kleszczami i chorobmi odkleszczowymi [The public health risk of ticks and tick-borne diseases in the south-eastern Poland]. Ann Parasitol. 2004;50(2):249-252 (in Polish).

4. Bartosik K., Sitarz M., Szymańska J., Buczek A.: Tick bites on humans in the agricultural and recreational areas in south-eastern Poland. Ann Agric Environ Med. 2011;18(1):151-157.

5. Cetin E., Sotoudeh M., Auer H., Stanek G.: Paradigm Burgenland: risk of Borrelia burgdorferi sensu lato infection indicated by variable seroprevalence rates in hunters. Wien Klin Wochenschr. 2006;118(21-22):677681.

6. Cisak E., Chmielewska-Badora J., Zwoliński J., Dutkiewicz J., Patorska-Mach E.: Ocena częstości zakażeń wirusem kleszczowego zapalenia mózgu i krętkami Borrelia burgdorferi wśród rolników indywidualnych na terenie Lubelszczyzny [The incidence of tick-borne encephalitis virus and Borrelia burgdorferi infections in farmers of the Lublin province]. Med Pr. 2003;54(2):139-144 (in Polish).

7. CisakE., Chmielewska-Badora J., Zwoliński J., WójcikFatla A., Zając V., Skórska C., Dutkiewicz J.: Study on Lyme borreliosis focus in the Lublin region (eastern Poland). Ann Agric Environ Med. 2008;15(2):327-332, doi:10.13075/mp.5893.2014.017.

8. Cisak E., Zwoliński J., Chmielewska-Badora J., Dutkiewicz J., Wójcik-Fatla A., Zając V.: Analysis of the state of knowledge and awareness in the area of tick-borne diseases prophylaxis in the population at occupational risk. Zdr Publ. 2011;121(1):47-51.

9. Czarkowski M.P., Cielebąk E., Staszewska-Jakubik E., Kondej B.: Choroby zakaźne i zatrucia w Polsce w 2017 roku [Infectious diseases and poisonings in Poland in 2017]. Warszawa: Narodowy Instytut Zdrowia Publicznego - Państwowy Zakład Higieny, 2018.

10. Deutz A., Fuchs K., Nowotny N., Auer H., Schuller W., Stünzner D., Aspöck H., Kerbl U., Köfer J.: Seroepidemiological studies of zoonotic infections in hunters-comparative analysis with veterinarians, farmers and abattoir workers. Wien Klin Wochenschr. 2003;115(supl.3):61-67 (in German).

11. Gazi H., Özkütük N., Ecemis Ö., Atasoylu G., Köroglu G., Kurutepe S., Horasan G.D.: Seroprevalence of West Nile virus, Crimean-Congo hemorrhagic fever virus,
Francisella tularensis and Borrelia burgdorferi in rural population of Manisa, western Turkey. J Vector Borne Dis. 2016;53(2):112-117.

12. Hügli D., Moret J., Rais O., Moosmann Y., Erard P., Malinverni R., Gern L.: Tick bites in a Lyme borreliosis highly endemic area in Switzerland. Int J Med Microbiol. 2009;299(2):155-60, doi: 10.1016/j.ijmm.2008.06.001.

13. Kubo N., Arashima Y., Kawabata M., Kawano K., Nakao M., Miyamoto K.: Study of the anti Borrelia burgdorferi antibody of hunters in Hokkaido. Kansenshogaku Zasshi. 1992;66(1):45-50 (in Japanese).

14. Pańczuk A., Koziol-Montewka M.: Exposure to ticks and preventive actions in the scope of Lyme disease among young people from the northern part of Lublin province (eastern Poland). Health Problems of Civilization. 2017;11(1):45-52, doi:10.5114/hpc.2017.65522.

15. Pańczuk A., Koziol-Montewka M., Tokarska-Rodak M.: Exposure to ticks and seroprevalence of Borrelia burgdorferi among a healthy young population living in the area of southern Podlasie, Poland. Ann Agric Environ Med. 2014;21(3):512-517.

16. Richard S., Oppliger A.: Zoonotic occupational diseases in forestry workers - Lyme borreliosis, tularemia and leptospirosis in Europe. Ann Agric Environ Med. 2015;22(1):43-50.

17. Stafford K.C.: Tick management handbook. Bulletin No 1010. South Windsor (CT): The Connecticut Agricultural Experiment Station; 2007. Available at: https://publichealth.yale.edu/eip/projects/completed/ handbook_54964_284_8219_v1.pdf (Accessed 20.11.2018)

18. Stanek G., Wormser G.P., Gray J., Strle F.: Lyme borreliosis. Lancet. 2012;379:461-473.

19. Tokarska-Rodak M., Plewik D., Koziol-Montewka M., Szepeluk A., Paszkiewicz J.: Ryzyko zakażeń zawodowych Borrelia burgdorferi u pracowników leśnictwa i rolników [Risk of occupational infections caused by Borrelia burgdorferi among forestry workers and farmers]. Med Pr. 2014;65(1):109-117 (in Polish), doi:10.13075/mp.5893.2014.017.

20. Trombert-Paolantoni S., Ferquel E., Postic D.: Retrospective study of Lyme borreliosis positive serologies in 2003. Pathol Biol (Paris). 2005;53(89):522-526 (in French).

21. Tylewska-Wierzbanowska S., Chmielewski T: Tickborne bacterial diseases in Poland. Health Problems of Civilization. 2017;11(2):56-65, doi:10.5114/ hpc.2017.69017.

22. Wierzbicka A., Raczka G., Skorupski M., Michalik J., Lane R.S.: Human behaviors elevating the risk of exposure to Ixodes ricinus larvae and nymphs in two types of lowland coniferous forests in west-central Poland. Ticks Tick Borne Dis. 2016;7(6):1180-1185, doi: 10.1016/j.ttbdis.2016.07.018.

23. Wilhelmsson P., Lindblom P., Fryland L., Nyman D., Jaenson T.G.T, Forsberg P., Lindgren P.: Ixodes ricinus ticks removed from humans in Northern Europe: seasonal pattern of infestation, attachment sites and duration of feeding. Parasit Vectors. 2013;6:362, doi:10.1186/1756-3305-6-362. 
24. Zajkowska J., Lewczuk P., Strle F., Stanek G.: Lyme Borreliosis: From Pathogenesis to Diagnosis and Treatment. Clin Dev Immunol. 2012: 231657, doi:10.1155/2012/231657.

25. Zákutná L., Dorko E., Mattová E., Rimárová K.: Sero-epidemiological study of Lyme disease among high-risk population groups in eastern Slovakia. Ann Agric Environ Med. 2015;22(4):632-636, doi: 10.5604/12321966.1185765.

26. Zielińska-Jankiewicz K., Kozajda A.: Wiedza wybranych grup zawodowych o rodzajach czynników biologicznych obecnych w środowisku pracy oraz o sposobach ochrony przed ich szkodliwym wpływem [The workers' knowledge about biological agents occurring in work environment and the ways of health protection against occupational exposure to biological hazards]. Med Pr. 2003;54:399-406 (in Polish).

Received: 05.03.2019

Accepted: 02.04.2019 